\title{
Toxoplasma gondii molecular and immunological identification and risk factors associated with infection in chicken slaughtered at Triângulo Mineiro region, Minas Gerais, Brazil
}

\author{
Identificação molecular e imunológica de Toxoplasma gondii e \\ fatores de risco associados com infecção em galinhas abatidas \\ na região do Triângulo Mineiro, Minas Gerais, Brasil
}

\author{
Karina Costa Coelho GONÇALVES'1; Maria Regina Reis AMENDOEIRA²; Kênia de Fátima CARRIJO;; \\ Daniela LELES ${ }^{1}$; Guilherme Mendes Borges NUNES³; Adriana Pittella SUDRÉㅎ Gabriela Cardoso GÓES; \\ Rodrigo Caldas MENEZES ${ }^{4}$; Patricia Riddell MILLAR ${ }^{1}$

\begin{abstract}
${ }^{1}$ Universidade Federal Fluminense, Departamento de Microbiologia e Parasitologia, Laboratório de Parasitologia, Niterói - RJ, Brazil ${ }^{2}$ Instituto Oswaldo Cruz, Laboratório de Toxoplasmose e outras Protozooses, Rio de Janeiro - RJ, Brazil

${ }^{3}$ Universidade Federal de Uberlândia, Faculdade de Medicina Veterinária, Uberlândia - MG, Brazil

${ }^{4}$ Fundação Oswaldo Cruz, Instituto Nacional de Infectologia Evandro Chagas, Laboratório de Pesquisa Clínica em Dermatozoonoses em Animais Domésticos, Rio de Janeiro - RJ, Brazil
\end{abstract}

\begin{abstract}
This study aimed to determine the occurrence of anti-Toxoplasma gondii antibodies in the serum of slaughtered chickens in the region of Triângulo Mineiro, Minas Gerais, Brazil, to detect the parasite in tissues (heart and brain) of serologically positive chickens, based on molecular analysis, and to investigate risk variables associated with the infection. Sera from 417 chickens raised in extensive, semi-intensive, and intensive production systems were tested by an indirect immunofluorescent antibody test (IFAT) and indirect hemagglutination antibody test (IHA). Polymerase chain reaction (PCR) was performed to detect T. gondii DNA in brain and heart tissues. Antibody anti-T. gondii were found in $37.65 \%$ (157/417) of chickens by IFAT, and in 75.06\% (313/417) by IHA. The Kappa index showed a weak concordance between the techniques (0.087). Association was observed between seropositivity and the variables, age $(p<0.0001)$, type of feeding $(p<0.0001)$ and collective raising with other animal's species $(p<0.0001)$. Association, based on IFAT, was not observed between seropositivity and the variables, $\operatorname{sex}(p=0.0526)$, presence of cats $(p>0.9999)$, and presence of rats $(p>0.9999)$. Presence of parasite DNA was detected in brain samples from two chickens, which were raised in intensive and semi-intensive production systems. The results suggest the meat of these slaughtered animals may serve as a transmission source of this protozoan to humans.
\end{abstract}

Keywords: Toxoplasma gondii. Gallus gallus domesticus. Serology. Molecular diagnosis.

\section{Resumo}

O objetivo do presente estudo foi determinar a frequência de anticorpos anti-Toxoplasma gondii em soro de galinhas abatidas na região do Triângulo Mineiro, Minas Gerais, detectar molecularmente o parasito em tecidos (coração e cérebro) de algumas das aves sorologicamente positivas e averiguar variáveis de risco associadas à infecção. Foram testados soros de 417 galinhas, criadas nos sistemas extensivo, semi-intensivo e intensivo. Para a pesquisa de anticorpos anti-T. gondii foi utilizada a Reação de Imunofluorescência Indireta (RIFI) e Hemaglutinação Indireta (HAI). A Reação em Cadeia da Polimerase (PCR) foi utilizada para detectar o DNA de T. gondii em fragmentos de cérebro e coração. Anticorpos foram detectados no soro de 37,65\% (157/417) das aves pela RIFI e em 75,06\% (313/417) pela HAI. O índice Kappa mostrou uma fraca concordância entre as técnicas $(0,087)$. Baseado na RIFI, foi verificada associação estatisticamente significativa $(\mathrm{p}<0,0001)$ entre a soropositividade e as variáveis: idade, tipo de alimentação e criação em conjunto com outras espécies animais. Não foi observada associação estatística $(p>0,01)$ entre as variáveis: sexo, presença de gatos e presença de ratos. Pelo diagnóstico molecular DNA do parasito foi detectado em duas amostras de cérebro, de indivíduos diferentes criados em sistema intensivo e semi-intensivo. Os resultados indicam a possibilidade de a carne dessas aves poderem atuar como fonte de infecção deste protozoário para o homem.

Palavras-chave: Toxoplasma gondii. Gallus gallus domesticus. Sorologia. Diagnóstico molecular. 
Correspondence to:

Patricia Riddell Millar

Universidade Federal Fluminense, Instituto Biomédico

Rua Prof. Hernani Melo, 101, São Domingos

CEP: 24210-130. Niterói, Brazil

e-mail: patriciariddell@vm.uff.br

Received: $12 / 03 / 2018$

Approved: 09/10/2018

\section{Introduction}

Toxoplasmosis is a worldwide zoonosis caused by Toxoplasma gondii, an obligate intracellular parasite for which felines are the definitive hosts, and humans and other endothermic animals are intermediate hosts (SILVA et al., 2006). Viable forms of this parasite have been isolated from meat products, and serological studies in Brazil show the infection of farm animals is widespread (BRANDÃO et al., 2006; MILLAR et al., 2008; GONÇALVES et al., 2012).

The ingestion of raw or undercooked chicken meat or eggs can transmit toxoplasmosis to definitive or intermediate hosts. Handling raw chicken without ensuring that proper sanitary measures are maintained can also be a route of transmission to human beings. Chickens may be used as sentinel animals since infection in this species is considered a good indicator of soil contamination by $T$. gondii oocysts (LITERAK and HEJLICEK, 1993; DUBEY, 2002; HILL and DUBEY, 2013). However, toxoplasmosis signs in chickens are not common (DUBEY, 2010a).

The development of strategies to control toxoplasmosis depends on the knowledge of the epidemiological aspects of the disease (FAJARDO et al., 2013), and the identification of risk factors is critical for the development of production systems that suitably promote animal health, and consequently avoid meat production containing infective forms of this parasite.

The Triângulo Mineiro region, in the state of Minas Gerais, Brazil, is an important national agricultural area for livestock. Nevertheless, reports on the epidemiological aspects of toxoplasmosis in chickens in this region are scarce. A recent study in this region was carried out in the city of Uberlândia, in which the authors verified high seropositivity (71.3\%) in chickens raised in an extensive production system (LOPES et al., 2016). Therefore, the aim of this study was to determine the prevalence of anti- $T$. gondii antibodies in the chickens of the region and to identify possible risk factors associated with the infection, and, based on molecular analysis, to detect the parasite in chickens that tested positive by immunological diagnosis.

\section{Materials and Methods}

Sera from chickens $(n=417)$ aged between 27 and 120 days old, which were raised in intensive, semi-intensive, and extensive production systems in the Triângulo Mineiro region ( $17^{\circ} 55^{\prime} 05^{\prime \prime}$ to $20^{\circ} 26^{\prime} 35^{\prime \prime} S$ and $45^{\circ} 38^{\prime} 25^{\prime \prime}$ to $51^{\circ} 02^{\prime} 47^{\prime \prime}$ W), MG, Brazil, were used in the study. The samples were collected during the slaughter of the birds, approved during ante-mortem inspection, in abattoirs with official sanitary inspection service.

Blood samples $(8 \mathrm{~mL})$ were collected and properly identified in tubes without anticoagulant. The samples were allowed resting at room temperature (approximately $21^{\circ} \mathrm{C}$ ) until clot retraction occurred, and then centrifuged at 5000 $\mathrm{rpm}$ for $3 \mathrm{~min}$. The samples were analyzed by the presence of $T$. gondii antibodies by the indirect hemagglutination antibody test (IHA) and indirect immunofluorescent antibody test (IFAT). The IHA test was performed using a commercial kit (Toxotest HAI ${ }^{\oplus}$, Wiener Lab.), at a dilution of 1:16, following the manufacturer's protocol. IFAT was performed, according to the protocol by Camargo (1964), using tachyzoites of RH (SABIN, 1941) strain of T. gondii as antigen. Chicken serum samples previously tested by IFAT were used as positive and negative control. Animals were considered positive when the antibody titration value was $\geq 16$ (MILLAR et al., 2012).

Part of the animals in this study $(\mathrm{n}=100)$ were selected for tissue collection (heart and brain). Among these animals, the heart and brain tissues of $25 \mathrm{~T}$. gondii seropositive chickens were randomly selected. Fifty samples (25 heart and 25 brain tissue samples) were processed for total DNA extraction using a PureLink Genomic DNA Kit (Invitrogen, USA), according to the manufacturer's recommendation, and the DNA was eluted in a final volume of $50 \mu$ l. To evaluate the presence of inhibitors in the samples, $1 \mu$ of DNA extracted from a sample of dog blood previously tested to confirm the absence of inhibitors was added to $1 \mu$ of each chicken DNA sample from this study. The mixed DNA samples were used as template in a PCR assay, in which a fragment of the gene encoding mitochondrial cytochrome $b$ of dogs was amplified.

Following the confirmation of the absence of PCR inhibitors, the study samples were subjected to T. gondiispecific PCR amplification. The PCR included the primers Tg-NP1 (5'-GTGATAGTATCGAAAGGTAT-3') and 
Tg-NP2 (5'ACTCTCTCTCAAATGTTCCT-3'), which specifically amplify a 227-bp fragment of the ITS1 region of Toxoplasma gondii (HURTADO et al., 2001). PCR was performed for a final volume of $50 \mu \mathrm{l}$, containing $1 \mathrm{X}$ TAE buffer, $2 \mathrm{mM} \mathrm{MgCl}$ 2, $0.2 \mathrm{mM}$ dNTP mix, $200 \mathrm{ng}$ of each primer, $2.5 \mathrm{U}$ of Taq polymerase Platinum (Invitrogen), and $5 \mu \mathrm{l}$ of the DNA extracted in this study as the template. The samples were amplified in a thermocycler under the following conditions: $94^{\circ} \mathrm{C}$ for $5 \mathrm{~min}$, followed by 40 sequential cycles of $94{ }^{\circ} \mathrm{C}$ for $20 \mathrm{~s}, 55^{\circ} \mathrm{C}$ for $20 \mathrm{~s}$, and $72{ }^{\circ} \mathrm{C}$ for $30 \mathrm{~s}$, followed by an extension at $72{ }^{\circ} \mathrm{C}$ for $7 \mathrm{~min}$, according to a protocol previously standardized by our group (LELES et al., 2016). DNA obtained from peritoneal lavage of mice infected with $T$. gondii strain $\mathrm{RH}$ and nuclease-free water were used as positive and negative controls, respectively. The PCR products were analyzed by electrophoresis on $2 \%$ agarose gels, with a 50-bp molecular weight marker (Promega, USA) as a size standard. The gel was stained with ethidium bromide for visualization of the PCR fragments, and photo documentation was performed using L-Pix (Loccus). The PCR amplicons were purified using an Illustra ${ }^{\mathrm{mm}}$ GFX $^{\mathrm{mu}}$ PCR DNA and Gel Band Purification Kit (GE Healthcare Life Sciences, Germany), according to the protocol of the manufacturer, and were then direct sequenced using a Big Dye Terminator kit (Applied Biosystems, USA) and an ABI-Prism 3130 sequencer. The sequences obtained were edited and analyzed using Chromas v.2.1.1 and Bioedit v.7.1.9 software and were further compared with sequences deposited in GenBank using the BLAST algorithm (https://blast.ncbi.nlm.nih.gov).

The farm owners and/or abattoir technical manager completed an epidemiological questionnaire with information about the production systems used for raising the animals involved in the study. The information are related to age, gender, diet, contact with cats and rodents, type of production system for raising the chickens, collective raising with other animals, and type of water source.

The serological results and epidemiological variables were analyzed using GraphPad Prism 7 software. The degree of agreement between the serological tests was evaluated using Cohen's Kappa (K) coefficient. The association between two categorical variables was determined using Pearson chi-square test $\left(\chi^{2}\right)$. Tables formed by two rows and two columns were evaluated using Fisher's exact test with a significance level of $p<0.05$. To evaluate the impact among the variables, odds ratio (OR) values were determined with their respective confidence interval (CI) of $95 \%$.
The Ethical Committee for Animal Use/Laboratory Animal Nucleus (CEUA/NAL) of Universidade Federal Fluminense approved this study (register \#320/13).

\section{Results}

The occurrence of birds with anti-T. gondii antibodies was of $37.65 \%$ (157/417) and 75.06\% (313/417), based on the IFAT and IHA assays, respectively. A weak agreement was observed between these serological techniques $(\kappa=0.087$, Table 1$)$. Because of this weak agreement, IFAT was considered as the gold standard for serological diagnosis, and only samples that tested positive by this technique were considered for the analysis of variables.

Among the animals that tested positive by IFAT, two showed an antibody titer of 1:4096 (1.28\%). The most prevalent antibody titer was $1: 16(\mathrm{n}=84 ; 53.50 \%)$, followed by $1: 64(\mathrm{n}=41 ; 26.11 \%), 1: 256(\mathrm{n}=22 ; 14.01 \%)$, and $1: 1024$ $(\mathrm{n}=8 ; 5.10 \%)$.

The analysis of epidemiological variables (Table 1) showed the number of females was greater than the number of males, with the proportions being $67.15 \%(280 / 417)$ and $32.85 \%$ (137/417), respectively. A total of $61.15 \%(96 / 157)$ of the positive chickens were female, and $38.85 \%(61 / 157)$ were male. Association was not observed between the variable sex and the sample positivity $(p=0.0526)$.

To evaluate T. gondii seropositivity, the birds were divided into age groups as follows: 27 to 41 days, 53 to 120 days, and above 120 days. Table 1 shows statistically significant association $(\mathrm{p}<0.0001)$ between age and serological results obtained. The odds ratio for $T$. gondii-specific antibodies in chickens older than 120 days was 4.6 times higher than in other age groups. Regarding the type of production system, the occurrence of $T$. gondii positive animals raised in extensive systems was $47.65 \%$, with 142 positive animals out of 298 , and the value decreased to only $13.86 \%$ ( 14 from 101 birds) in animals raised in intensive systems. Only one chicken from semi-intensive system was seropositive (1/18).

Regarding the animal's type of feed, $75.78 \%$ (316/417) were fed with commercial ration and pasture, and $24.22 \%$ (101/417) were fed with ration only. Regarding the water source, $69.06 \%$ (288/417) ingested water from unknown sources (sources not provided by the farm owners), $24.22 \%$ (101/417) from artesian wells, and 6.72\% (28/417) from springs. A total of $73.38 \%$ (306/417) of chickens were raised close to other animals, such as other avian species (ducks, geese, and duckweeds) and dogs, and 26.62\% (111/417) were not collectively raised around other animals. 
Table 1 - Distribution of slaughtered chicken in the Uberlândia municipality, Triângulo Mineiro, between August 2015 and January 2016, according to possible risk factors for Toxoplasma gondii infection

\begin{tabular}{|c|c|c|c|c|c|c|}
\hline Variable & $\begin{array}{l}\text { Reagent* } \\
\text { n (\%) }\end{array}$ & $\begin{array}{c}\text { Not Reagent } \\
\text { n (\%) }\end{array}$ & $\begin{array}{l}\text { Total } \\
\text { n (\%) }\end{array}$ & O.R. & $\begin{array}{l}\text { C.I. } \\
(95 \%)\end{array}$ & $p$-value \\
\hline Sex & & & & & & 0.0526 \\
\hline Female & 96 (34.29) & $184(65.71)$ & $280(100)$ & & & \\
\hline Male & $61(44.53)$ & $76(55.47)$ & $137(100)$ & 0.65 & $0.4281-0.987$ & \\
\hline Total & $157(37.65)$ & $260(62.35)$ & $417(100)$ & & & \\
\hline Age (days) & & & & & & $<0.0001$ \\
\hline $27-41^{+}$ & $9(16.36)$ & $46(83.64)$ & $55(100)$ & & & \\
\hline $53-120$ & $12(16.22)$ & 62 (83.78) & $74(100)$ & 0.9892 & $0.3846-2.5444$ & \\
\hline$>120$ & $136(47.22)$ & $152(52.78)$ & $288(100)$ & 4.5731 & $2.1582-9.6901$ & \\
\hline Total & $157(37.65)$ & $260(62.35)$ & $417(100)$ & & & \\
\hline Rearing system & & & & & & $<0.0001$ \\
\hline Extensive $^{+}$ & $142(47.65)$ & $156(52.35)$ & $298(100)$ & & & \\
\hline Semi-intensive & $1(5.56)$ & $17(94.44)$ & $18(100)$ & 0.0646 & $0.0085-0.4918$ & \\
\hline Intensive & $14(13.86)$ & $87(86.14)$ & $101(100)$ & 0.1748 & $0.0962-0.3249$ & \\
\hline Total & $157(37.65)$ & $260(62.35)$ & $417(100)$ & & & \\
\hline Feeding & & & & & & $<0.0001$ \\
\hline Ration & $14(13.86)$ & $87(86.14)$ & $101(100)$ & 0.1947 & $0.1062-0.357$ & \\
\hline Ration/Pasture & $143(45.25)$ & $173(54.75)$ & $316(100)$ & & & \\
\hline Total & $157(37.65)$ & $260(62.35)$ & $417(100)$ & & & \\
\hline Water source & & & & & & $<0.0001$ \\
\hline Artesian well & $14(13.86)$ & $87(86.14)$ & $101(100)$ & 0.1799 & $0.0977-0.331$ & \\
\hline Spring & $7(25)$ & $21(75)$ & $28(100)$ & 0.3725 & $0.1536-0.9307$ & \\
\hline Unknown ${ }^{+}$ & $136(47.22)$ & $152(52.78)$ & $288(100)$ & & & \\
\hline Total & $157(37.65)$ & $260(62.35)$ & $417(100)$ & & & \\
\hline Collective raising & & & & & & $<0.0001$ \\
\hline No & $20(18.02)$ & 91 (81.98) & $111(100)$ & 0.2711 & $0.59-0.4624$ & \\
\hline Yes & $137(44.77)$ & $169(55.23)$ & $306(100)$ & & & \\
\hline Total & $157(37.65)$ & $260(62.35)$ & $417(100)$ & & & \\
\hline
\end{tabular}

${ }^{*}$ Reagent - Seropositive to antibodies anti-Toxoplasma gondii by IFAT, $\mathrm{n}$ - Number of birds

${ }^{+}$Reference category for OR calculation

The correlation between possible risk factors and chicken positivity showed $91.08 \%$ (143/157) of positive animals were fed with ration and pasture, and $87.26 \%$ (137/157) were raised among other animals, both of them with statistical significance $\mathrm{p}<0,0001$. All chickens used in this study came from properties where the presence of cats and rats were reported, then these variables did not present a statistically significant association with the positive serology of the samples analyzed ( $p>0.9999)$.

The molecular analysis revealed that none of the samples contained detectable PCR amplification inhibitors. For the targeted amplification of the T. gondii ITS1 sequence, two brain tissue samples (CE37 and CE87) were PCR positive with expected amplicons of $227 \mathrm{bp}$, as well as the positive control (Figures 1 and 2). These two samples that showed amplification of the T. gondii gene target came from individuals with different characteristics. The CE37 sample was obtained from a 120-day-old male chicken raised in a semi-intensive system. The CE87 sample was obtained from a 55-day-old female chicken raised in an intensive system. However, the two DNA sequences obtained from these two different individuals were identical to each other, and showed $100 \%$ sequence similarity with several reference strains of T. gondii (KX459518.1, KM657806.1, JQ235841.1, JX456456.1, among others) available in the GenBank database. The sequence obtained in this study was deposited in GenBank with the accession number KX853130. 


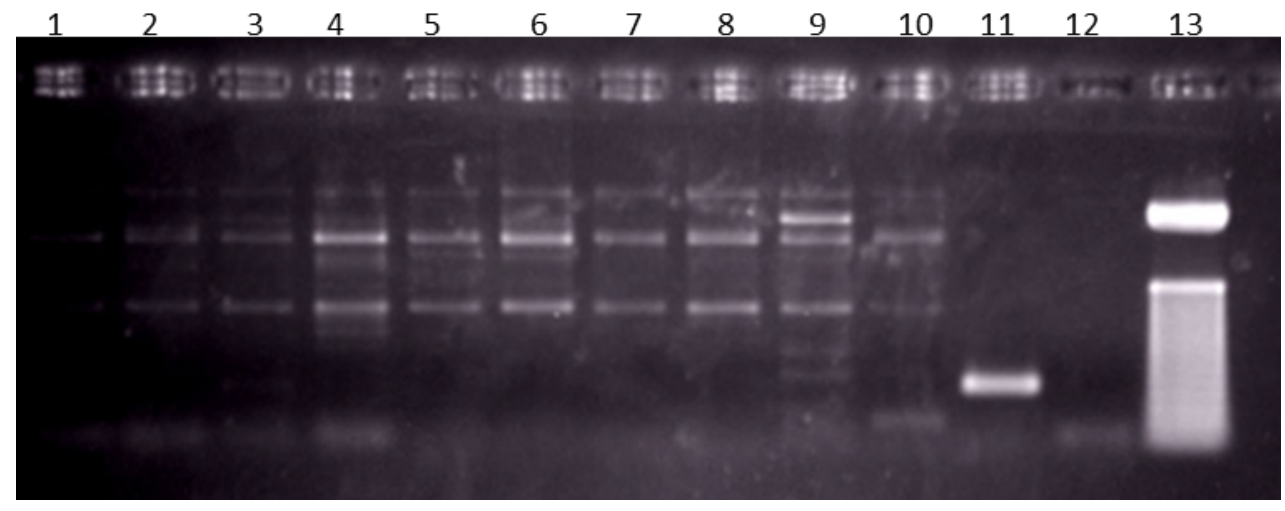

Figure 1 - Amplifications for the ITS1 gene target of Toxoplasma gondii in brain tissue of chicken from this study

Lanes 1 to 10: DNA from tested samples; Lane 11: positive control (peritoneal lavage of infected mouse / Rh strain); Lane 12: negative control (nuclease-free water); Lane 13: molecular weight marker of 50bp. The rectangle indicates the amplification of one of the samples (CE37) at the expected height according to the positive control

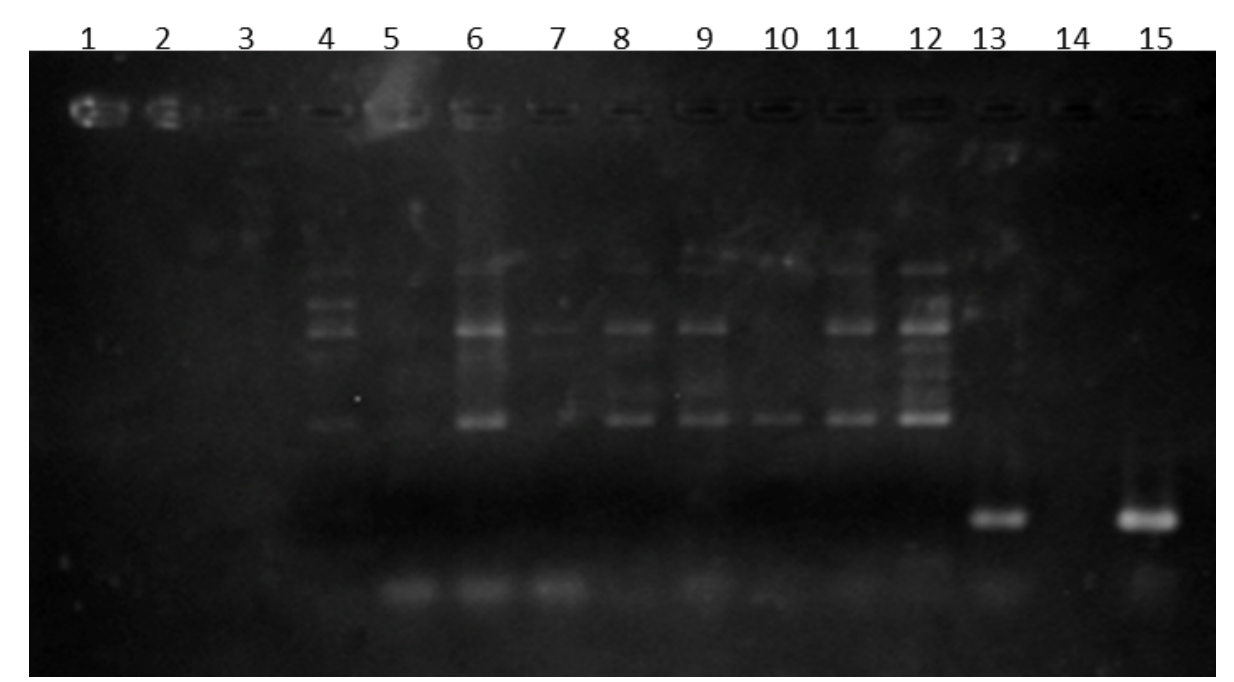

Figure 2 - Amplifications for the ITS1 gene target of Toxoplasma gondii in brain tissue of chicken from this study

Lanes 1 to 13: DNA from tested samples; Lane 14: negative control (nuclease-free water); Lane 15: positive control (peritoneal lavage of infected mouse / Rh strain). The rectangle indicates the amplification of one of the samples (CE87) at the expected height according to the positive control

\section{Discussion}

The practice of consuming raw or undercooked meat increases the risk of infection by T. gondii (DUBEY, 1994; SCHLINDWEIN and KASSOUF, 2006). Studies performed in Brazil indicate that the prevalence of T. gondii in chickens raised in extensive production systems ranges from 10.3\% - 100\% (GARCIA et al., 2000; OLIVEIRA et al., 2009). Factors, such as the level of environmental contamination, type of production system, and climate can contribute to a wide range of results observed (DUBEY et al., 2006; MILLAR et al., 2012; YAN et al., 2016).

In this study, the frequency of chickens detected positive by IFAT $(39.10 \%)$ was high, considering that the animals came from different breeding systems. This positivity rate was greater than that reported by other investigators in the state of Paraná, Rio de Janeiro and
Bahia (GARCIA et al., 2000; GONÇALVES et al., 2012; MILLAR et al., 2012). However, other studies from the states of Rio de Janeiro and Minas Gerais found higher positivity rates than those detected in this study (BONNA et al., 2006; BRANDÃO et al., 2006). Differences in the frequencies of positivity for T. gondii in chickens may be associated with different levels of infectivity in the studied environments or variations in sensitivity among diagnostic techniques (GARCIA et al., 2000). Although the studies cited above used the same serological technique of this study, other factors should be considered, such as the climate of each region, exposure to the etiological agent, number of animals surveyed, and management conditions. In this study, IFAT was considered as the gold standard for serological diagnosis. Although the IHA test was also performed, the agreement with IFAT 
was weak. The IHA test used was standardized for use in humans, and its results indicate that it is not suitable for the use in birds.

The predominance of infection in older chickens compared with that in younger ones is in part likely to be due to an increase in the cumulative effect of exposure to the parasite by adult animals, that is, with the increase in the age of a bird, the likelihood of it becoming infected by T. gondii oocysts present in the environment also increases (DUBEY, 2010b). Although the number of females slaughtered was higher than that of males, no association was found between seropositivity for T. gondii and the sex of the chickens, corroborating the findings of Bonna et al. (2006) and Feitosa et al. (2016).

The presence of cats and rats were reported for all the properties studied, then they could not be analyzed as risk factor. The existence of cats in those properties possibly provided rodent control. However, rodents can be an important infection source for both cats and chickens, which can become infected by ingestion of tissue containing parasite cysts.

In this study, a statistical association was observed between the type of feeding and the positivity occurrence of chickens. The percentage of positive animals was much higher among those fed with ration and pasture. This result suggests these animals were more exposed to environmental contamination by the oocysts, thus confirming the role of birds as indicators of environmental contamination by T. gondii. Feitosa et al. (2016) did not show an association between these two variables when chickens from five municipalities in the state of Paraíba were analyzed. Despite the researchers had not shown statistic association, the percentage of positive hens fed with ration and pasture was higher than that of those fed exclusively with ration.

Water is an important source for T. gondii dissemination due to the long survival of oocysts in the environment; therefore, water may be considered as important as food as risk factor (TENTER et al., 2000; BAHIA-OLIVEIRA et al., 2003; CENCI-GOGA et al., 2013). Association between water source and seropositive hens was reported by Camillo (2015) when carrying out a study with 597 domestic chickens in Rio Grande do Sul, Brazil. Unfortunately, in spite of its relevance, the association between the water source and the seropositive results cannot be considered, since the water source was unknown for most of the infected animals evaluated in this study.
In this study, $87.18 \%(136 / 156)$ of the seropositive chickens were collectively raised with other animals. An important observation is that, in this case, not breeding with other animals may act as a protective factor against T. gondii infection, with interbreeding being an important factor for the occurrence of infection.

For the molecular analysis, the organs of choice for obtaining samples for DNA extraction and PCR amplification were the brain and heart. Yan et al. (2010) evaluated chickens in China and reported that the organs with the highest number of T. gondii parasites are the heart and lungs, and Aigner et al. (2010) demonstrated amplification of $T$. gondii DNA from brain and heart in samples of poultry in Paraná, Brazil. In general, molecular analysis studies are conducted on the brain and the heart samples because of the parasite's natural predilection for these organs. In this study, T. gondii DNA was positively amplified from the brain tissue of 2 out of 25 animals selected for molecular analysis. The amount of DNA was not enough to allow the genotype of the $T$. gondii strain.

Although determining the viability of the parasite by PCR is not possible, the results corroborate the fact that the consumption of this type of meat may be a risk for the consumer, particularly if the meat or viscera is not properly cooked (MILLAR et al., 2012; FERNANDES et al., 2016).

\section{Conclusions}

This study is relevant, since toxoplasmosis is a neglected zoonosis with wide distribution and once the knowledge garnered from these data may help in delineating more specific studies regarding the epidemiology of the parasite. The high frequency of positive animals in the IFAT analysis, together with the direct detection of parasite DNA in tissue samples (brain), calls attention towards the risk of human infection by T. gondii via consumption of infected chicken meat.

\section{Conflict of interest}

The authors declare no conflicts of interest and are responsible for the content and writing of this article.

\section{Acknowledgements}

The authors thank CAPES and FAPERJ for financial support and the Plataforma de Sequenciamento de DNA of the Universidade Federal Fluminense for the DNA sequencing of samples. 


\section{References}

AIGNER, C. P.; DA SILVA, A. V.; SANDRINI, F.; OSÓRIO, P. S.; POIARES, L.; LARGURA, A. Real-time PCR-based quantification of Toxoplasma gondii in tissue samples of serologically positive outdoor chickens. Memórias do Instituto Oswaldo Cruz, v. 105, n. 7, p. 935-937, 2010. doi: 10.1590/S0074-02762010000700018.

BAHIA-OLIVEIRA, L. M.; JONES, J. L.; AZEVEDOSILVA, J.; ALVES, C. C.; ORÉFICE, F.; ADDISS, D. G. Highly endemic, waterborne toxoplasmosis in north Rio de Janeiro state, Brazil. Emerging Infectious Diseases, v. 9, n. 1, p. 55-62, 2003. doi: 10.3201/eid0901.020160.

BONNA, I. C. F.; FIGUEIREDO, F. B.; DA COSTA, T.; VICENTE, R. T.; SANTIAGO, C. A. D.; NICOLAU, J. L.; DAS NEVES, L. B.; MILLAR, P. R.; SOBREIRO, L. G.; AMENDOEIRA, M. R. R. Estudo soroepidemiológico da infecção por Toxoplasma gondii em suínos e frangos, para abate, em região rural do Rio de Janeiro. Revista Brasileira de Ciência Veterinária, v. 13, n. 3, p. 186-189, 2006. doi: 10.4322/rbcv.2014.296.

BRANDÃO, G. P.; FERREIRA, A. M.; MELO, M. N.; VITOR, R. W. A. Characterization of Toxoplasma gondii from domestic animals from Minas Gerais, Brazil. Parasite, v. 13, n. 2, p. 143-149, 2006. doi: 10.1051/ parasite/2006132143.

CAMARGO, M. Improved technique of indirect immunofluorescence for serological diagnosis of toxoplasmosis. Revista do Instituto de Medicina Tropical de São Paulo, v. 6, n. 3, p. 117-118, 1964. Available from: <http://www.imt.usp.br/wp-content/uploads/revista/ vol06/117-118.pdf $>$. Viewed: Nov. 16th, 2018.

CAMILLO, G. Toxoplasma gondii em galinhas domésticas: epidemiologia, isolamento e caracterização molecular. 2015. 87 f. Tese (Doutorado em Medicina Veterinária) - Centro de Ciências Rurais, Universidade Federal de Santa Maria, Rio Grande do Sul, 2015.

CENCI-GOGA, B. T.; CIAMPELLI, A.; SECHI, P.; VERONESI, F.; MORETTA, I.; CAMBIOTTI, V.; THOMPSON, P. N. Seroprevalence and risk factors for Toxoplasma gondii in sheep in Grosseto district, Tuscany,
Italy. BMC Veterinary Research, v. 9, n. 25, p. 1-8, 2013. doi: 10.1186/1746-6148-9-25.

DUBEY, J. P. Toxoplasmosis. Journal of the American Veterinary Medical Association, v. 205, n. 11, p. 1593$1598,1994$.

DUBEY, J. P. A review of toxoplasmosis in wild birds. Veterinary Parasitology, v. 106, n. 2, p. 121-153, 2002. doi: 10.1016/S0304-4017(02)00034-1.

DUBEY, J. P.; GENNARI, S. M.; LABRUNA, M. B.; CAMARGO, L. M.; VIANNA, M. C.; MARCET, P. L.; LEHMANN, T. Characterization of Toxoplasma gondii isolates in free-range chickens from Amazon, Brazil. Journal of Parasitology, v. 92, n. 1, p. 36-41, 2006. doi: 10.1645/GE-655R.1.

DUBEY, J. P. Toxoplasma gondii infections in chickens (Gallus domesticus): prevalence, clinical disease, diagnosis and public health significance. Zoonoses and Public Health, v. 57, n. 1, p. 60-73, 2010a. doi: 10.1111/j.18632378.2009.01274.x.

DUBEY, J. P. Toxoplasmosis of animals and humans. Boca Raton: CRC Press, 2010b. 313 p.

FAJARDO, H. V.; D’ÁVILA, S.; BASTOS, R. R.; CYRINO, C. D.; DETONI, M. L.; GARCIA, J. L.; NEVES, L. B.; NICOLAU, J. L.; AMENDOEIRA, M. R. R. Seroprevalence and risk factors of toxoplasmosis in cattle from extensive and semi-intensive rearing systems at Zona da Mata, Minas Gerais state, Southern Brazil. Parasites \& Vectors, v. 6, n. 191, p. 1-8, 2013. doi: 10.1186/1756-3305-6-191.

FEITOSA, T. F.; VILELA, V. L. R.; ALMEIDA-NETO, J. L.; SANTOS, A.; MORAIS, D. F.; ATHAYDE, A. C. R.; AZEVEDO, S. S.; PENA, H. F. J. First study on seroepidemiology and isolation of Toxoplasma gondii in free-range chickens in the semi-arid region of Paraíba state, Brazil. Parasitology Research, v. 115, n. 10, p. 39833990, 2016. doi: 10.1007/s00436-016-5164-5.

FERNANDES, M. F. T. S.; CAVALCANTI, E. F. T. S. F.; SILVA, J. G.; MOTA, A. R.; NETO, O. L. S.; SANTOS, A. 
S.; ALBUQUERQUE, P. P. F.; LIMA, D. C. V.; MOTA, R. A. Occurrence of anti-Toxoplasma gondii antibodies and parasite DNA in backyard chicken breeding in Northeast, Brazil. Revista Brasileira de Parasitologia Veterinária, v. 25, n. 1, p. 105-108, 2016. doi: 10.1590/S1984-29612016012.

GARCIA, J. L.; NAVARRO, I. T.; OGAWA, L.; MARANA, E. R. M. Soroprevalência do Toxoplasma gondii em galinhas (Gallus gallus domesticus) de criações domésticas, oriundas de propriedades rurais do norte do Paraná, Brasil. Ciência Rural, v. 30, n. 1, p. 123-127, 2000. doi: 10.1590/S0103-84782000000100020.

GONÇALVES, I. N.; UZÊDA, R. S.; LACERDA, G. A.; MOREIRA, R. R. N.; ARAÚJO, F. R.; OLIVEIRA, R. H. M.; CORBELLINI, L. G.; GONDIM, L. F. P. Molecular frequency and isolation of cyst-forming coccidia from free ranging chickens in Bahia State, Brazil. Veterinary Parasitology, v. 190, n. 1-2, p. 74-79, 2012. doi: 10.1016/j.vetpar.2012.05.007.

HILL, D. E.; DUBEY, J. P. Toxoplasma gondii prevalence in farm animals in the United States. International Journal for Parasitology, v. 43, n. 2, p. 107-113, 2013. doi: 10.1016/j. ijpara.2012.09.012.

HURTADO, A.; ADURIZ, G.; MORENO, B.; BARANDIKA, J.; GARCÍA-PÉREZ, A. L. Single tube nested PCR for the detection of Toxoplasma gondii in fetal tissues from naturally aborted ewes. Veterinary Parasitology, v. 102, n. 1-2, p. 17-27, 2001. doi: 10.1016/ S0304-4017(01)00526-X.

LELES, D.; LOBO, A.; RHODES, T.; MILLAR, P. R.; AMENDOEIRA, M. R. R.; ARAÚJO, A. Recovery of Toxoplasma gondii DNA in experimentally mummified skin and bones: prospects for paleoparasitological studies to unveil the origin of toxoplasmosis. Experimental Parasitology, v. 168, p. 51-55, 2016. doi: 10.1016/j. exppara.2016.06.003.

LITERAK, I.; HEJLICEK, K. Incidence of Toxoplasma gondii in population of domestic birds in the Czech Republic. Avian Pathology, v. 22, n. 2, p. 275-281, 1993. doi: 10.1080/03079459308418920.

LOPES, C.S.; FRANCO, P. S.; SILVA, N. M.;SILVA, D. A.O.; FERRO, E. A. V., PENA, H. F. J.; MINEO, J. R. Phenotypic and genotypic characterization of two Toxoplasma gondii isolates in free-range chickens from Uberlândia, Brazil. Epidemiology \& Infection, v. 144, n. 9, p. 1865-1875, 2016. doi: $10.1017 / S 0950268815003295$.

MILLAR, P. R.; SOBREIRO, L. G.; BONNA, I. C. F.; AMENDOEIRA, M. R. R. The importance of food animals in the infection for Toxoplasma gondii in Brazil. Semina: Ciências Agrárias, v. 29, n. 3, p. 693-706, 2008. doi: 10.5433/1679-0359.2008v29n3p693.

MILLAR, P. R.; ALVES, F. M. X.; TEIXEIRA, V. Q.; VICENTE, R. T.; MENEZES, E. M.; SOBREIRO, L. G.; PEREIRA, V. L. A. P.; AMENDOEIRA, M. R. R. Occurrence of infection with Toxoplasma gondii and factors associated with transmission in broiler chickens and laying hens in different raising systems. Pesquisa Veterinária Brasileira, v. 32, n. 3, p. 231-236, 2012. doi: 10.1590/S0100-736X2012000300009.

OLIVEIRA, L. N.; COSTA JUNIOR, L. M.; DE MELO, C. F.; RAMOS, J. C. S.; BEVILAQUA, C. M.; AZEVEDO, S. S.; MURADIAN, V.; ARAUJO, D. A.; DUBEY, J.P.; GENNARI, S. M. Toxoplasma gondii isolates from free-range chickens from the northeast region of Brazil. The Journal of Parasitology, v. 95, n. 1, p. 235-237, 2009. doi: 10.1645/GE-1730.1.

SABIN, A. B. Toxoplasmic encephalitis in children. Journal of the American Medical Association, v. 116, n. 9, p. 801-807, 1941. doi: 10.1001/jama.1941.02820090001001.

SCHLINDWEIN, M. M.; KASSOUF, A. L. Análise da influência de alguns fatores socioeconômicos e demográficos no consumo domiciliar de carnes no Brasil. Revista de Economia e Sociologia Rural, v. 44, n. 3, p. 549-572, 2006. doi: 10.1590/S0103-20032006000300009.

SILVA, F. W. S.; ALVES, N. D.; AMÓRA, S. S. A.; TEXEIRA, F. H. V.; ACCIOLY, M. P.; CARVALHO, C. G.; NÓBREGA, R. M.; FILGUEIRA, K. D.; FEIJÓ, F. M. C. Toxoplasmosis: uma revisão. Ciência Animal, v. 16, n. 2, p. 71-77, 2006. Available from: <http://www.uece. $\mathrm{br} /$ cienciaanimal/dmdocuments/Artigo2.2006.2.pdf $>$. Viewed: Nov 16th, 2018.

TENTER, A. M.; HECKEROTH, A. R.; WEISS, L. M. Toxoplasma gondii: from animals to humans. 
International Journal for Parasitology, v. 30, n. 12-13, p. 1217-1258, 2000. doi: 10.1016/S0020-7519(00)00124-7.

YAN, C.; YUE, C. L.; YUAN, Z. G.; LIN, R. Q.; HE, Y.; YIN, C. C.; XU, M. J.; SONG, H. Q.; ZHU, X. Q. Molecular and serological diagnosis of Toxoplasma gondii infection in experimentally infected chickens. Veterinary
Parasitology, v. 173, n. 3-4, p. 179-183, 2010. doi: 10.1016/j. vetpar.2010.07.011.

YAN, C.; LIANG, L.; ZHENG, K.; ZHU, X. Impact of environmental factors on the emergence, transmission and distribution of Toxoplasma gondii. Parasites \& Vectors, v. 9, n. 137, p. 1-7, 2016. doi: 10.1186/s13071-016-1432-6. 